\title{
IMAGENS DE VELHICE, IMAGENS DA INFÂNCIA: FORMAS QUE SE PENSAM
}

FABIANA BRUNO*

ETIENNE SAMAIN ${ }^{* *}$

RESUMO: Dando prioridade ao trabalho das imagens e ao trabalho conjunto da memória, o ensaio procura, ao abrir algumas perspectivas heurísticas e metodológicas, entender como as pessoas idosas reconstroem, a partir de fotografias, por elas previamente selecionadas e montadas, os panoramas de suas infâncias.

Palavras-chave: Memória. Velhice. Fotografia. Trabalho das imagens.

\section{IMAGES OF OLD-AGE, IMAGES OF CHILDHOOD:} FORMS THAT THINK ABOUT THEMSELVES

ABSTRACT: Prioritizing the joint work of images and memory, and pointing out some heuristic and methodological perspectives, this essay aims at understanding how old people reconstruct their childhood panorama based on previously selected and organized pictures.

Key words: Memory. Old age. Photography. Work of the images.

* Doutoranda do Programa de Pós-Graduação em Multimeios, na área de Antropologia Visual, na Universidade Estadual de Campinas (UNICAMP).E-mail: fabybruno@uol.com.br

* Doutor em Ciências Teológicas e Religiosas pela Universidade Católica de Lovaina (Bélgica) e professor titular do Departamento de Cinema da UNICAMP. E-mail: samain@unicamp.br

Cad. Cedes, Campinas, vol. 26, n. 68, p. 21-38, jan./abr. 2006

Disponível em <http://www.cedes.unicamp.br> 
Imagens de velhice, imagens da infância: formas que se pensam

\section{O universo da pesquisa}

R

etratos da velhice (Bruno, 2003) propôs uma aproximação do universo das pessoas idosas na tentativa de descobrir, com elas, questões em torno do "trabalho da memória visual", quando pessoas na sua velhice - interrogam tanto suas fotografias como suas próprias existências e biografias: o que se guarda, se elege e se conserva. A proposta apresenta reflexóes decorrentes das potencialidades das fotografias (visualidade), quando se trata de pensarmos sobre como a memória de pessoas idosas se constrói e se organiza por meio de imagens.

A pesquisa desenvolveu-se com cinco pessoas, homens e mulheres, com faixa etária entre 70 e 80 anos, que nem sempre se conheciam, mas que tinham em comum o fato de ter a sua disposição um "baú" ou, pelo menos, uma coleção pessoal de fotografias reunidas ao longo de sua vida. A cada uma dessas pessoas idosas, após todo um período de reconhecimento mútuo, foi solicitada uma única e mesma tarefa: dedicar-se à revisitação do conjunto dessas fotografias pessoais para escolher 20 imagens - mais ou menos - que melhor pudessem representar a sua própria trajetória de vida. Os contatos pessoais - entre pesquisadora e informantes - prolongaram-se, até o dia em que cada um se sentiu pronto para apresentar sua escolha e comentar espontaneamente ${ }^{1}$ as suas fotos preferidas.

Desta forma, os idosos ofereceram dados visuais e verbais à pesquisa. Primeiro, escolheram e - sem ter necessariamente consciência do fato - montaram um conjunto visual da ordem de 20 fotografias. Somente depois, com base nos registros imagéticos que tinham diante dos olhos, é que se puseram a relatar, a partir das fotografias e com elas, suas memórias, suas experiências de vida, sua visão de mundo e de uma sociedade das quais se sentem, sempre, os atores. Os dados tinham se multiplicado e as questões também.

Diante do grande volume de fotografias recolhidas e do não menos complexo conjunto de evocaçóes a que deram espaço, a pesquisa, para se tornar viável, exigia um recorte. Propusemos assim aos cinco informantes idosos uma nova tarefa: selecionar apenas 10 , do conjunto de cerca de 20 fotografias já apresentadas. Após repetirem o mesmo procedimento envolvendo o processo de escolha, cada um deles nos ofereceu um outro e simultâneo registro oral de suas impressões, decorrentes de um novo trabalho da memória, isto é, de um novo percurso da memó- 
ria, induzido e produzido pelo rearranjo e pela reformulação das próprias "formas" sígnicas contidas nas fotografias.

À luz deste horizonte operacional, desenvolvemos propostas exploratórias, as quais, pensamos, puderam enriquecer a questão do trabalho da memória das pessoas idosas e da sua singular arquitetura, quando ousam dar credibilidade às imagens.

As fotografias selecionadas e escolhidas, incluídas e excluídas, pelos informantes são fragmentos de memória na composição (recomposição) de uma história de sua vida. São, por outro lado, duas coleções de pequenas peças visuais ordenadas, duas seqüências ou, melhor dizendo, dois pequenos filmes que nos falam de uma existência. No âmbito desta pesquisa metodológica exploratória, oferecemos algumas pistas preliminares de investigação visual e, em especial, a proposta de como poderíamos ver e ler essas montagens, espécies de panoramas existenciais. Propomos neste ensaio três formas de leitura: visual horizontal e linear, vertical ou em colunas e visual circular.

\section{Forma visual horizontal e linear}

A primeira forma consiste em ler o conjunto das fotografias como se suas imagens fossem "enunciados" (visuais) da memória do informante, "frases" (visuais), ou, ainda, como se, de maneira orquestral, compusessem um texto. A leitura se daria, pelo menos através de nosso sistema de representação gráfica, da esquerda para a direita e de cima para baixo, um modo ao qual estamos bastante acostumados. Mas será que isso basta para responder a essa outra questão: a das implicaçōes lógicas e cognitivas que tal traçado opera sobre o trabalho da memória e, conseqüentemente, sobre a natureza das informações e das lembranças que ela irá recolhendo?

\section{Forma visual vertical ou em colunas}

A leitura da segunda proposta, também metodológica, divide em etapas sucessivas as enunciações visuais da memória. Se antes líamos frases visuais lineares, horizontais, agora temos uma forma vertical que nos apresenta a coleção de fotografias do informante em três colunas. Ao realizar a leitura de cima para baixo e de uma coluna para outra, existe uma quase

Cad. Cedes, Campinas, vol. 26, n. 68, p. 21-38, jan./abr. 2006 
Imagens de velhice, imagens da infância: formas que se pensam

obrigatória interrupção desta leitura, impondo-nos uma parada antes de podermos prosseguir. Tal formato de leitura, não-habitual na sociedade ocidental, provoca-nos um estranhamento, quase um mal-estar.

Despidos da estranheza da leitura, no entanto, o sistema em colunas, surpreendentemente, nos impulsiona a enxergar essas peças visuais (imagens), constituindo-se em três fases, três "colunas", espécies de vigas que dão sustentação horizontal à construção de toda uma existência. Diferentemente da situação anterior, estamos diante de outras implicaçóes lógicas e cognitivas sobre o trabalho da memória, que ainda nos faltam desvendar.

\section{Forma visual circular}

A terceira proposta de leitura trata de uma forma circular. O círculo apresenta as fotografias do informante, não somente referenciando a forma ao tempo que passa, o tempo do relógio, mas a um tempo que compõe uma história de vida, ou seja, o ciclo. Desta maneira, o conjunto circular nos conduz à exploração de conexões, correspondências e aproximaçóes entre as fotografias, que antes apareciam distanciadas ou, no mínimo, impensadas.

Não impondo-nos apenas um sentido de leitura horário, ou antihorário, a forma circular nos oferece múltiplas leituras em função das infinitas associações entre imagens, peças visuais e traçados: leituras diagonais, transversais, perpendiculares e também circulares. Seria a forma circular a que melhor representaria a dinâmica da vida do trabalho da memória?

Olhar para a prancha fotográfica circular, novamente como uma enunciação visual, é permitir, de outra forma, que deste arranjo nasça uma "singular história" de memória. E, no caso, a que novas implicações lógicas e cognitivas sobre o trabalho da memória estaríamos nos referindo?

$$
* * *
$$

Quando nos propusemos a dar prioridade às fotografias, sabíamos que as imagens carregavam um potencial de revelação e uma capacidade de dialogar entre si. Entravam numa "correspondência", no sentido comunicacional do termo, isto é, estabeleciam, entre elas, uma rede de signos e de significaçôes. Desta maneira, entendemos que os traçados de 
formas horizontal, vertical e circular, desenhados em torno do conjunto de fotografias de cada informante, estruturam, entre as imagens, pensamentos associativos distintos. As exploraçōes que apresentamos até aqui em torno das diferentes formas de leitura das pranchas fotográficas apenas nos sugerem trabalhos que podem ser realizados com as próprias imagens, a partir do entrosamento da fotografia com o relato oral. As formas apresentadas não são, aliás, as únicas. ${ }^{2}$

Tendo delineado, a largas pinceladas, o universo da pesquisa, iremos nos deter daqui para frente a um trabalho muito mais minucioso, retomando, a partir de um material mais amplo, uma única prancha fotográfica circular para examiná-la de perto. Esta prancha dirá respeito a nossa primeira informante, Dona Celeste. Representará a sua segunda escolha e conseqüentemente, sua segunda montagem: um conjunto de 11 fotografias, como logo veremos.

Antes de chegar lá, julgamos oportuno oferecer ao leitor uma breve biografia de Dona Celeste, ${ }^{3}$ apresentada por ela mesma, uma espécie de "resumo de vida". Tratar-se-ia de um florilégio de evocaçōes espontâneas e de confidências que ela exprimia quando ordenava e montava, na nossa presença, as fotografias que havia escolhido. Uma outra razão nos conduz a esta breve apresentação de Dona Celeste: deixar claro que o fato de insistirmos sobre a dimensão expressiva e formal das imagens (e não somente despertadora) no trabalho da memória nunca será para minimizar a riqueza enunciativa da palavra.

\section{Dona Celeste por Dona Celeste}

(...) meu avô, pai de papai... Ah, olha só. E vieram pra cá [de Portugal], pro Brasil, aí nasceu meu pai, nasceu na Barra Funda... O papai... olha, a escolaridade do papai eu não sei bem, mas ele, com certeza, ele... tenha feito a escola antiga, que a gente falava primeiro ano, segundo ano, ele deve ter feito o colegial.

O papai também, papai escrevia muito, sabe... papai era muito inteligente. Aliás, meu pai cantava no circo, sabe? Então, ele cantava músicas caipiras, sertanejas, então, ele cantava!

Antes, bem antes de papai ser de circo, ele foi telegrafista, como conferente, depois foi chefe de estação e eu sei que a cidade estava até escrito aqui... eu devia ter escrito à caneta pelo menos né? Chamavam antigamente era

Cad. Cedes, Campinas, vol. 26, n. 68, p. 21-38, jan./abr. 2006 
Imagens de velhice, imagens da infância: formas que se pensam

Mayrinque Veiga, agora acho que cortaram o Veiga. Mas papai casou em mil oito... não, mil novecentos e doze.

A mamãe foi criada pela vó dela. Essa é mamãe e esta é a avó dela [mostra a fotografia], porque a mãe dela morreu quando ela, quer dizer, o nenê morreu na hora do parto. A mamãe era Maria Delfina. Delfina Lobo Pires. Só que ela não assinava Lobo.

Botucatu. A minha cidade, aonde eu nasci. Como eu não conhecia a minha cidade, o papai comprou essas duas [fotografias em cartōes-postais]. Aqui era a estação e aqui era um colégio, ele comprou essas duas pra mim, pra eu ver como é que era lá... tal. Como é que era? Não mostra a cidade! Vista do ginásio de Botucatu, a Cidade Progresso, uma lembrança da minha primeira visita, papapá, papapá... Itatinga, primeiro de março de 1940. Itatinga... é São João de Itatinga que chama. Mas ele me deu essa fotografia, essas duas fotografias, eu já era mocinha. Já era grande, tinha uns doze anos, mais ou menos.

Eu nunca tive coragem [de dançar no circo], porque quando eu era pequena, até uns doze anos, eu fazia trapézio, andava no arame, depois dos doze anos eu não quis mais. Aí pedi pra mamãe pedir pro papai, porque a gente não tinha voz ativa de pedir nada, né? Aí ele concordou que eu não fizesse mais. Porque eu tenho as pernas meio tortas e eu tinha vergonha de pôr roupinha curta pra... no arame tem que andar com roupa curta, trapézio tem que andar de maiô, uma coisa assim né, então eu não fiz mais, aí ele concordou.

Minha irmã era muito bonita, nesta época ela era solteira e eu também [mostra a foto], mas ela era muito bonita, ela tinha uns cabelos compridos, loiros, bem loirinhos... Aliás, eu que tratava do cabelo dela.

E mesmo pernas, ela tinha umas pernas muito bonitas, eu já não, eu já tenho a perna torta. Mas nós dançávamos, dançávamos até muito bem. Muitas vezes a gente precisava até repetir, bis.

Muitos achavam mesmo que eu era parecida com a Carmen Miranda. E Carmen Miranda pra mim foi um ídolo, eu gostava muito dela... Vesti como na época a gente podia... modesta né [sobre uma foto em que aparece vestida como Carmen Miranda]. Não era uma fantasia assim... muito... assim eu cantava. Tinha... era tudo nosso, né? Roupa, adereços... tudo era nosso, né? Eu era moça ainda... muita vontade de vencer na vida. Trabalhar! Era uma jovem cheia de ideais!

Nós tivemos em Atibaia e tinha um leiteiro que trazia todos os dias, com o circo, trazia todos os dias um litro de leite em casa. E um dia ele trouxe dois pintinhos, casalzinho e falou pra mim se eu gostava de criar. Falei: ah, gosto 
sim! Então ele deu, o casalzinho. E eles foram crescendo. Numa época de frio, nós nem estávamos mais em Atibaia, uma época de frio, eles pousavam no meu quarto, a guarda da cama, assim, dos pés, era o poleiro deles. Então, eu punha papel embaixo, tudo, no caso deles sujarem. E como tava frio, eu botei uma blusa minha no chão, velha, nem ocupava mais e eles se agachavam e ficavam lá, cocoradinhos, né e parecia que tinha frio mesmo, que ficavam ali, não subiam no poleiro deles lá do quarto.

Aí quando foi uma noite de frio ela se... foi entrando pela manga da minha blusa, era de lā, entrando pela manga, morreu sufocada!

Ai! eu senti tanto... Bom, daí foi. Ele chamava Menino [o galo], mas era tão ensinado que você precisa ver. Ficava na janela, gostava de ficar na janela, mas se alguém passasse e fizesse: que bonitinho! Ele picava. E não saía de perto de mim... Bom, quando eu fiquei noiva, nós tínhamos umas galinhas e tinha ele também né? Aí a mamãe falou: Celeste, porque que você não fala pro Walter [seu esposo], se a mãe dele tem terreno pra deixar as suas galinhas lá, seu Menino... Falei: tá, eu vou falar pra ele. Falei, ele disse: ah, pode mandar, minha mãe não se importa não. Então quando foi um dia, nós viemos aí na casa do Walter e deixamos lá as galinhas, tudo. Mas eu gostava dele [o galo], tinha saudades dele, no circo eu tinha saudades, vivia no meu quarto, vivia perto de mim sempre...

Tenho um livro. Eu já escrevi três livros, três contos pra o Banco Real...

A gente aprendia conforme os dramas, as comédias, assim, o que a gente não sabia, o valor da palavra, ou pontuação, ou a gente perguntava pro papai e ele dizia: vai consultar o livro dos burros, que era o dicionário, né? E assim, a gente foi aprendendo. É, primeiro ano, segundo ano eu estive [na escola], mas depois... Aí eu fui aprendendo no circo mesmo, porque a gente não tinha tempo pra ir à escola. A gente ficava pouco tempo num lugar, um mês, é, um mês, dois... no lugar e não dava [tempo]. Quer dizer, felizmente, com a graça de Deus, que me deu esse dom, eu não sou tão burra, eu escrevo um pouco.

[O casamento] Foi dezembro. Eu queria [o babado do vestido] de baixo em godê, pra depois pregar os babados. Eu queria que ficasse bem-rodado. A "bandida" [a costureira] não fez feito um saco?! É, ela fez um saco assim e pregou!

Não, não era... com babado sim, mas eu queria bem godê a parte e ela me fez isso daí. Ah, mas olha, eu senti tanto... chorei... Mas, o quê vou fazer?

Eu tive que aceitar, porque a gente não tinha dinheiro, circo não dava, principalmente em dezembro, tempo de chuva, quase a gente não trabalhava. O pano [para o vestido de casamento] mesmo foi o Walter [seu esposo] que 
Imagens de velhice, imagens da infância: formas que se pensam

me deu. Bom, quando nós casamos, eu estava doente, pra variar (risos), eu tava com úlcera no duodeno. Mas ele quis casar né, não quis adiar...

Então eu já estava meio doente. Foi com um pouco de sacrifício até que casamos, porque ele também, naquela ocasião, era empregado numa farmácia, não era rico, o pai era sapateiro, a mãe dona-de-casa, mas eles não eram ricos.

Mas como diz que o amor é cego, eu não sei o quê que ele viu em mim. Palavra! Olha, eu te juro, eu não sei o quê que esse moço viu comigo. Eu era pobre, não tinha riqueza, não tinha nada, nem dinheiro quase pro casamento eu não tinha; tava doente, era quatro anos mais velha que ele e finalmente eu era de circo, né? Você acha que uma família do lugar vai concordar, vai consentir que seu filho case com uma moça de circo, principalmente comigo que tinha todos esses defeitos? Mas graças a Deus casamos e fomos muito felizes até, muito! Ele era um homem muito bom, muito prestativo, ele não era de muito carinho, de muita coisa não, porque a mãe dele era assim: a mãe dele tinha um ciúme louco do filho... E às vezes, quando ele chegava em casa, da farmácia, que ele ia me beijar ela falava: vocês não tiveram tempo quando solteiros, agora vai ficar com esse melado aí? Ela falava, que ela brava...

Mas assim mesmo moramos dois anos na casa dela, que o que ele ganhava não dava pra... ele ajudava na casa, né?... não dava pra pagar um aluguel de casa. Depois, ele foi trabalhar em Pedreira, numa farmácia e depois quando viemos de lá [de Pedreira], eles compraram a farmácia. Eu voltei a morar com ela, porque não tinha lugar pra mim. Daí, ele... o que era o antigo dono da farmácia, nos cedeu um quarto. Aí eu passei da casa da minha sogra, nesse quartinho da farmácia, que tinha na farmácia. E ali eu fiquei três anos. Mas quando eu vim morar aí, eu já tinha minha primeira filha, a Ivani, e ali eu fiquei três anos e ali eu me engravidei outra vez, mas... aí eu falei pro Walter, eu não posso ficar mais aqui. O dono da casa, da farmácia, ele era muito, uma pessoa muito brava e ele me ofendia muito. Qualquer coisa ele soltava: nossa a casa tá cheirando ruim, mas isso é porque tem gente de circo morando aqui!

(...) a mãe era uma delícia de mulher, uma pessoa tão bondosa, tão amiga, mas ele era danado viu, ih credo, sofri muito. Os três anos que eu morei ali eu sofri bastante, porque ele tacava cada indireta... Tudo porque eu era de circo, né?

\section{Intermezzo: as imagens são "formas que (se) pensam"}

$\mathrm{Na}$ superfície e debaixo de toda imagem existe uma forma, um fundo, uma tela, um vazio a ser preenchido: uma forma para uma ima- 
gem que, ainda, há de nascer. É a partir, e por causa deste quadro, deste espaço (cego e branco) que a fala dos homens conseguiu designar e nomear as coisas deste mundo (que, previamente, lhes foram dadas a $v e r)^{4}$ e que a escrita (que não é mera transcrição da fala) conseguiu se tornar visivel. Ao reservar para um outro momento uma reflexão mais aprofundada sobre as relaçóes que a escrita, a fala, a imagem e a memória mantêm com essa "tela" originária (Christin, 1995; Samain, 1994), desprovida de inscrição, de designação ou de recordação, podemos antecipar essas três outras breves reflexões.

Toda imagem (um desenho, uma pintura, uma fotografia, um fotograma de cinema, uma imagem em vídeo, uma infografia...) é portadora de um pensamento, isto é, carrega e veicula um pensamento. Pelo menos, o do autor que a fez.

Toda imagem, por sua vez, nos faz pensar e sempre nos oferece algo para pensar: ora um pedaço de real para roer, ora uma faísca de imaginário para sonhar. "Não basta pensar para ver: a visão é um pensamento condicionado", lembrava Merleau-Ponty (1964, p. 52). Roland Barthes (1980) dizia essas coisas com outras palavras. Falava de Studium e de Punctum.

O que, no entanto, mais nos desconcerta é quando se atreve dizer que a imagem - toda imagem - é uma "forma que (se) pensa" (Arnheim, 1969; Aumont, 1996; Godard, 1998; Dubois, 2004). A proposição é tanto mais provocadora e complexa na medida em que reivindica e chega a dizer que, independentemente de nós, as imagens seriam formas que, entre elas, se comunicam e dialogam. Utopia ou verdadeiro desafio? Optamos, sem hesitação, pela segunda hipótese. Para responder minimamente, todavia, a tal interrogação, oferecemos a seguir duas breves reflexões. A primeira dirá respeito a um questionamento semelhante que poderíamos levantar com relação à escrita. A segunda remeterá ao modo singular, com o qual Aby Warburg (18661929), historiador da arte e fundador da iconologia moderna, encarava a questão do trabalho da memória e organizava sua biblioteca em Hamburgo.

No tocante à referência com a escrita, levantamos essa questão: por que conferimos - sem reticência alguma - à organização de palavras (por exemplo: um sujeito, um adjetivo, um verbo, um pronome relativo, um complemento direto ou indireto, um gerúndio ou um 
simples artigo...), numa frase qualquer, uma capacidade de ideação (isto é, essa possibilidade de suscitar um pensamento e "idéias")? Por que deveríamos, então, duvidar das potencialidades que os componentes sígnicos de uma imagem ou de várias imagens, ao se associarem, teriam a nos oferecer ideaçôes de outra ordem (em termos de formas, de traços, de cores, de movimentos, de vazios, de relevos, de interações, de outras pontuações sígnicas e significativas)?

Quanto a Aby Warburg, contemporâneo de Erwin Panofsky, de Ernst Gombrich (1970) e de Sigmund Freud, concebia a memória como uma montagem em constante ação e reação. Era, para ele, menos um estoque de conhecimentos que um princípio operatório e ativo de organização, de elaboração, de exploração e de compreensão das ações humanas. A memória era, para Warburg, uma espécie de hipertexto, algo já previsto por Borges em seu conto El Aleph (1949). ${ }^{5} \mathrm{Na}$ sua vasta biblioteca de Hamburgo - de forma semi-esférica - Warburg organizava as centenas de livros que recebia anualmente, ${ }^{6}$ numa coleção de questôes, isto é, de memórias vivas. Deslocava um livro [um saber] em direção a um outro [saber] que lhe era mais pertinente e complementar. Aproximava, por exemplo, um livro de filosofia sobre a arte antiga de um livro de arte renascentista, antes de inserir, entre os dois, um estudo sobre o Laocoon e seus filhos, e um outro sobre o ritual da serpente dos índios Pueblo.

Este encadeamento interminável de livros - dirá o filósofo Ernst Cassirer na oração fúnebre de Warburg - me aparecia como atravessado pelo sopro de um mágico que se mantinha suspenso, aplicando uma lei sobrenatural. E cada vez que me imergia na significação profunda desta biblioteca, cada vez mais essa impressão inicial reforçava-se e se confirmava. Do ordenamento dos livros emergia, sob uma forma sempre mais clara, uma série de imagens, de motivos determinados e de idéias originais, e atrás desta complexidade via finalmente surgir, com clareza, a figura forte do homem que tinha construído essa biblioteca, sua personalidade de pesquisador prometida a uma influência profunda. (Michaud, 1998, p. 226, nota 2)

Para Warburg, existia entre os livros, assim como nas dinâmicas da memória humana, uma lei: a "lei de boa vizinhança" (DidiHuberman, 2002). 
4. Quando imagens redesenham os caminhos da infância

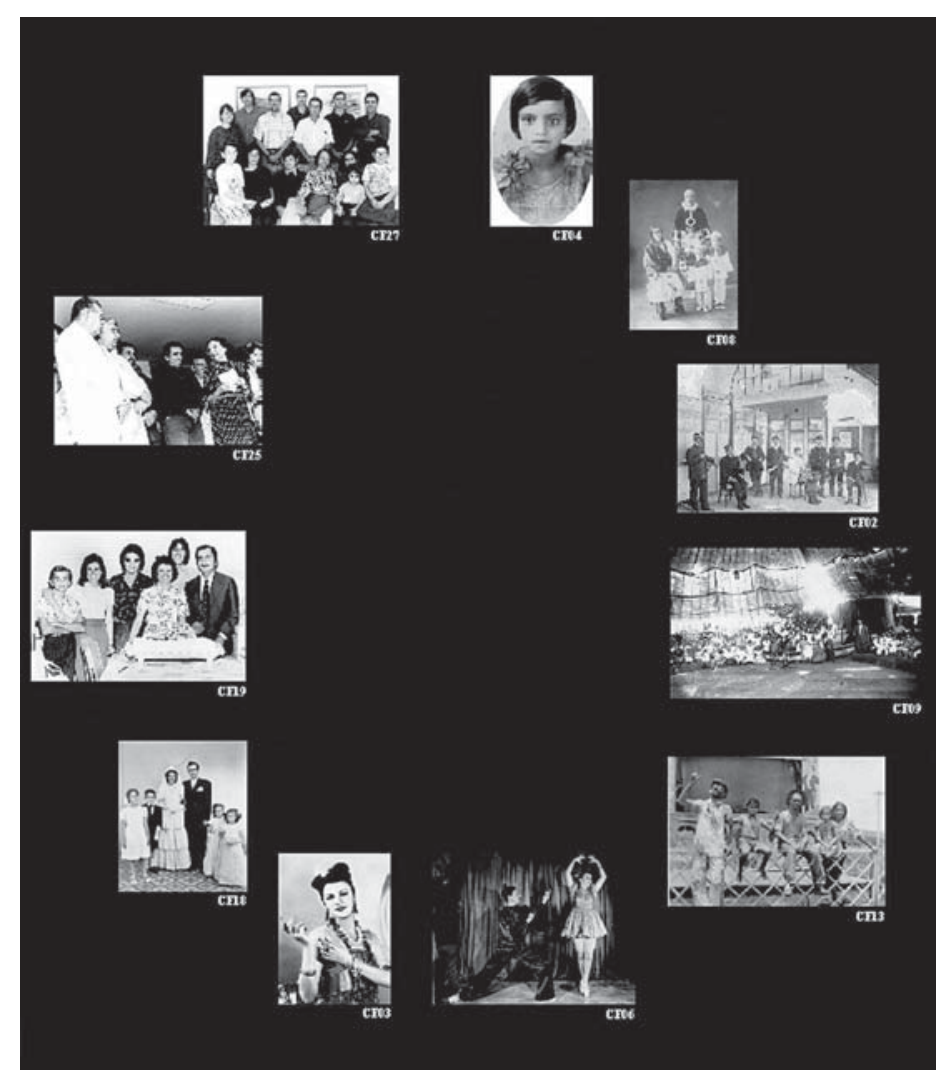

Uma primeira aproximação

Se partirmos da montagem circular das 11 fotografias escolhidas por Dona Celeste, observaremos - percorrendo o conjunto no sentido horário - que as sete primeiras vão definindo o que se poderia chamar o "tempo da juventude", quando as quatro últimas remetem ao "tempo da vida adulta", iniciada e consagrada na fotografia de casamento com o se- 
nhor Walter Ferrari. Em outras palavras, Dona Celeste, hoje com 84 anos de idade, privilegia claramente o período de uma vivência que antecede ao seu casamento. Este último, de certo modo, demarca e abre uma outra fase, um tempo que ela mesma qualificará de "recente" e que chamaríamos de "histórico", distinguindo-o do primeiro que, até certo ponto, já teria tomado para ela contornos de um tempo "mítico", precisamente por ser o tempo da infância, aquele dos "começos", do "era uma vez".

Formalmente, ainda, algo novo aflora lentamente e torna-se uma evidência, quando, deixando o nosso olhar explorar cada uma das mesmas figuras, percorremos o mesmo círculo das onze fotografias, solicitando dele e delas não precisões e provas e, sim, impressões e sensações visuais que, ao se conjugarem, nos falariam, nos "diriam" algo a partir, precisamente, de um "não dito". O que, desta vez, nos impressiona é a natureza temática profunda, ${ }^{7}$ presente nos dois conjuntos que acabamos de circunscrever. O leitmotiv visual que perpassa esses dois universos é, com efeito, o da "família". De um lado e fechando o círculo das fotografias, a "família nuclear" com três cenas festivas que podemos pressagiar como sendo encontros dos seus membros (filhos, noras e netos); do outro, uma série de outras representaçoos lúdicas e festivas (pessoas fantasiadas, picadeiro do circo, apresentação de bailado e, sobretudo, o diálogo formal que se estabelece entre os grandes olhos da menina e o rosto da moça vestida de Carmem Miranda), que deixam pressentir um outro universo: a "família dos artistas", a grande "família do circo".

Eis como, numa primeira aproximação do conjunto dessas 11 fotos, tanto as figuras como as formas se ordenam e, ao se associarem, iniciam uma verdadeira conversa entre si. Sem dúvida, estamos ainda muito longe de ter entendido claramente as escolhas feitas por Dona Celeste, ${ }^{8}$ menos ainda chegamos à possibilidade de penetrar, com maior precisão, na história de cada fotografia. Temos recolhido, todavia, através deste trabalho das imagens - independentemente de todo comentário externo -, pistas e traçados, indicativos e, para assim dizer, "sintomas" e prefigurações. Prefigurações não apenas da história de vida de Dona Celeste, mas, sobretudo, do trabalho da sua própria memória. Existe, pensamos, um trabalho das imagens imbricado ao trabalho da memória, e tudo indica que ambos os trabalhos procuram, na massa confusa das nossas lembranças, reminiscências e, sobretudo, esquecimentos, eleger, ressuscitar e instituir - graças às imagens e às suas polissemias - algumas configuraçôes de ordem temporal, espacial e temática. ${ }^{9}$ 
Podemos, agora, numa perspectiva que permanecerá formal e figural, mas que integrará, também, comentários verbais necessários de Dona Celeste, focalizar as sete fotografias do "tempo da sua juventude".

\section{Uma segunda aproximação}

Acabamos de chamar a atenção do leitor sobre a conivência que solda a primeira fotografia (os grandes olhos, ávidos e decididos, da menina) e a sétima (a moça incorporando Carmen Miranda). Trata-se, evidentemente, da mesma pessoa: Dona Celeste. Ela [registrada oficialmente por um fotógrafo contratado], no início de sua vida artística, quando, com cinco anos de idade, começou a dançar no circo, vestida com "uma roupa confeccionada pela sua máe", sua "primeira roupa para a apresentação". Dona Celeste, depois, com 19 anos de idade, quando "cantava no circo" e foi "a um estúdio fotográfico, vestida de Carmen Miranda, para ser fotografada". Acrescentará: "É a foto em que mais gosto de me ver".

Entre a foto 1 e a foto 7, cinco outras, as quais devemos desvendar, ou, melhor dizendo, "desarticular" na perspectiva de nossa pesquisa, cuja natureza, lembramos, reivindica uma "lei de boa vizinhança" (Warburg) à base de figuras e de formas que, ao associar-se, pensam entre si.

Não por acaso, a foto 4 ocupa um lugar central neste conjunto e representa nada mais, nada menos que "o picadeiro do circo 'Marabá' dos meus pais, em data próxima ao Natal". Quando se casando, Dona Celeste também se despedirá do circo. A triangulação, assim, formada pelas fotos 1-4-7 não poderia ser mais perfeita para sintetizar o que foi e permanecerá na memória de Dona Celeste, o mais importante e o mais essencial da sua juventude: o picadeiro, a "família do circo" e o que, ali, fazia: dançar e cantar.

Esse triângulo vem realçar esta "lei de boa vizinhança", à qual acabamos de nos referir. Ele demarca, com efeito, dois outros pequenos subconjuntos: as fotografias 2 e 3 , de um lado, e as fotografias 5 e 6 , do outro. Há de se confessar que, sem os comentários verbais fornecidos por Dona Celeste, seria difícil saber a que remetem essas quatro figuras. Notar-se-á, todavia, que, em termos visuais, as fotos 2 e 6 evocam, mais uma vez, o mundo do espetáculo (pessoas fantasiadas; apresentação de um bailado). ${ }^{10}$ Mas quem são essas pessoas representadas? Por quais razões 
Imagens de velhice, imagens da infância: formas que se pensam

foram convocadas pela memória da informante? Eis o que Dona Celeste diz de cada uma delas:

Foto 2: "É uma recordação da família numa época de Carnaval. É a minha mãe, Maria Delfina Lobo Pires da Costa [à esquerda sentada], o meu pai, José Pires [no centro] e os meus irmãos, Artur e José". [Grifos nossos]

Foto 3: "É uma lembrança da profissão do meu pai em ocupação fora do circo. É o meu pai, já casado, na época em que foi chefe da Estação de Mayrinque, 'ao lado dos telegrafistas e maquinista' [outra pequena família] com um livro nas mãos, num tempo em que já estava 'escrevendo peças'”. [Grifos nossos]

Foto 5: "É uma fotografia que traz recordações de uma época de dificuldade para a familia circense. Foi em Carandaí, no dia em que o circo se transformou em parque antes de ser vendido". [Grifos nossos]

Foto 6: "É lembrança das apresentaçôes com minha irmã, no picadeiro do circo da família. Eu [à esquerda] cantava e a minha irmã era a principal dançarina”. [Grifos nossos]

Nesta segunda aproximação, vimos que o trabalho formal entre as imagens permaneceu importante, mas, ao mesmo tempo, nos deixou ante a uma série de imprecisóes, de silêncios ou, simplesmente, de questôes que somente as informaçóes verbais de Dona Celeste foram capazes de elucidar.

\section{Uma terceira aproximação}

A interatividade entre visual e verbal é tal que nos obriga a realizar uma terceira aproximação, que desenvolveremos em dois momentos e a partir de dois exemplos.

- Acabamos, na série de sete fotografias que remetem ao "tempo da juventude" e "à família do circo", de dar relevo a dois subconjuntos (fotos 2 e 3; fotos 5 e 6) que, efetivamente, nos reportam aos familiares de Dona Celeste (pai, mãe irmãos e irmã), às atividades profissionais do pai (homem circense, chefe de estação e escritor de peças) e das filhas (uma canta, outra dança nas apresentaçôes circenses). Perguntamos: será que a cumplicidade, entre as imagens e as temáticas suscitadas, terminaria ali, tratando-se do trabalho múltiplo da "memória"?

Para não nos alongarmos, focalizaremos apenas o subconjunto das fotos 5 e 6, mostrando os comentários que Dona Celeste fazia des- 
sas duas fotografias. Com relação à primeira, dirá: "Que cabelo horrível... sempre trançando as perninhas para não parecer as pernas tão tortas" e, com relação à outra: "Uma recordação de nossos bailados... fiz o vestido dela (irmã)... eu já tinha um cabelão comprido... já tinha as pernas tortas... Minha irmã era muito bonita... tinha os cabelos compridos, loiros, bem loirinhos". Estes elementos reincidentes (cabelos, pernas), verbais, no caso, são outros elos, entrelaçamentos importantes, à medida que apresentam recordaçōes (e imagens) mais profundamente embrenhadas nas camadas da memória, revelando-nos outras vertentes da personalidade sensível e feminina de Dona Celeste.

- Deixamos, desde nossa primeira aproximação visual do conjunto das 11 fotografias, três delas num certo esquecimento por pertencerem a um "tempo da vida adulta", situado após o casamento de Dona Celeste com o Seu Walter. É necessário, no entanto, voltar ao que nos revelam essas três fotografias, com base nas declaraçôes de Dona Celeste:

Foto 9: "Fotografia em que se encontram reunidos os meus filhos". Dona Celeste (ao centro), o marido Walter Ferrari (à direita) e os filhos (da esquerda para direita), Vanderlei, Ivani, Walter Ferrari Júnior e Ivan, em reunião comemorativa de Bodas de Prata (grifos nossos).

Foto 10: "Recordação da homenagem prestada ao meu marido". Trata-se do momento do discurso de Dona Celeste, durante a inauguração do Hospital Municipal de Jaguariúna - que leva o nome do marido, Walter Ferrari, falecido em 5 de outubro de 1990 - com a presença do governador Luis Fleury e do então prefeito, Laércio Gothardo (grifos nossos).

Foto 11: "Fotografia em que se encontra toda a família reunida". Uma fotografia de 1989, na residência de Dona Celeste, com seus filhos, noras e netos (grifos nossos).

As informações verbais de Dona Celeste confirmam as significações presentes nas imagens por ela escolhidas, ou seja, entre a "família circense" e a "família nuclear" existem laços extremamente profundos, assim como, para ela, paradoxais. Para entender a natureza deste paradoxo, podemos reler o que diz Dona Celeste (ponto 2):

Mas como diz que o amor é cego, eu não sei o que é que ele [seu futuro marido] viu em mim. Palavra! Olha, eu te juro, eu não sei o quê que esse moço viu comigo. Eu era pobre, não tinha riqueza, não tinha nada, nem dinheiro quase pro casamento eu não tinha; tava doente, era quatro anos mais velha que ele e finalmente eu era de circo, né? Você acha que uma família do

Cad. Cedes, Campinas, vol. 26, n. 68, p. 21-38, jan./abr. 2006 
Imagens de velhice, imagens da infância: formas que se pensam

lugar vai concordar, vai consentir que seu filho case com uma moça de circo, principalmente comigo que tinha todos esses defeitos?

O círculo das fotografias se fecha. Dona Celeste, com lucidez, confirma: "pertencia à família do circo" (isto é tudo o que podia significar - na época); hoje, a minha "família está toda reunida" e eu vivo ainda entre ela.

\section{Curta conclusão}

Realizamos uma tripla abordagem das 11 fotografias escolhidas por Dona Celeste. Abordagens que dão conta daquilo que permanece, hoje, central na sua memória e que, ao mesmo tempo, configuram o essencial da sua vida: a sua família múltipla e única (a "vida no circo" e a "vida familiar"). Esta tríplice aproximação privilegiou a vertente visual presente, pensamos, não apenas no trabalho da memória, mas, de maneira um tanto quanto fantasmagórica (isto é, na sombra permanente de sobrevivências), também, no âmago do trabalho das imagens, quando fazem aliança e selam um pacto silencioso enquanto figuraçôes.

Há de se acrescentar que as imagens sempre foram e serão telas, quadros, fundos, vazios capazes de engendrar, ora formas visuais, ora verbais, ora escritas (isto é: desenhos, palavras, textos). A palavra nasce da imagem e a escrita é uma imagem. Dito isso, ter-se-ia notado que nunca minimizamos, no decorrer deste ensaio, o poder de enunciação da palavra e a sua importância na rememoração daquilo que qualificamos como sendo uma "história" e, sobremaneira, uma "vida". Resta, sim, dar à memória humana um redimensionamento necessário e dinâmico. Talvez, a memória tem algo a ver com o mar. Ela é um fluxo e um refluxo contínuo de ondas, de gritos e de silêncios, de mistérios, de naufrágios e de tesouros escondidos.

Recebido em setembro de 2005 e aprovado em março de 2006

\section{Notas}

1. Comentários de certo modo muito singulares, na medida em que decorriam e se processavam no vai-e-vem de um olhar posto sobre cada imagem e perpassando, ao mesmo tempo, o conjunto das imagens. Esses relatos foram naturalmente gravados. São estes comen- 
tários que apresentaremos parcialmente na parte 2, quando ofereceremos ao leitor aspectos da história de vida de uma das informantes: Dona Celeste.

2. Dentre outros arranjos visuais, aqui não apresentados pela impossibilidade de espaço, assinalamos as seguintes formas: a) Apresentar lado-a-lado, numa mesma prancha, as duas coleções montadas pelo informante. b) Apresentar também, numa mesma prancha, essas duas coleções numa disposição: horizontal, vertical e circular. c) Apresentar numa justaposição o primeiro conjunto de fotografias seguido do segundo e de um terceiro, onde se destaca, por meio de janelas (quadros) brancas, as imagens que "sumiram" e foram excluídas entre a primeira escolha e a segunda. d) Pensar de maneira horizontal, vertical e circular o conjunto das fotografias excluídas na constituição da primeira para a segunda coleção, na medida em que tais exclusóes representam, pensamos, uma outra história.

3. Parece-nos interessante demarcar que a biografia de Dona Celeste, apresentada em suas próprias palavras neste artigo, é consequiência de um exercício inverso daquele desenvolvido durante a pesquisa, quando toda a biografia (relatada de forma verbal) somente nascia, emergia, a partir da visualidade das fotografias, como decorrência das imagens e, portanto, quase indissociada delas. Notamos, na escrita deste artigo, que a história de vida de Dona Celeste, quando distante de suas fotografias, ou seja, quando apoiada apenas pela oralidade de seus comentários, torna-se simplificada, resumida, para não dizer quase "esvaziada de palavras", na ausência de imagens.

4. É interessante observar que o tema de "nominação" das coisas do mundo pelo homem é o princípio de muitos mitos de criação e, mais ainda, que tal "nominação" se faz com base em desenhos ou modelagens/esculturas, imagens prévias dessas coisas. O Deus dos Dogon, por exemplo, "desenha", investindo os seus desenhos de seu pensamento criador. Depois ele leva os seus desenhos para os homens e são eles que os decifram e os nomeiam. O mais velho relato bíblico da criação (Gênesis 2,4ss) é, deste ponto de vista comunicacional, absolutamente extraordinário.

5. Devemos esse feliz “link" referencial ao professor e amigo Eduardo Peñuela Cañizal.

6. Possuía mais de 65.000 volumes em 1927.

7. O que não deve significar a única.

8. Devemos imaginar que ela, também, não tem a "evidência" das suas escolhas.

9. Trata-se evidentemente de uma hipótese de trabalho. Tal propósito somente poderá se tornar operativo e pertinente a partir de uma rede de informantes suficientemente representativa, o que pretendemos alcançar em desdobramentos futuros deste trabalho.

10. É interessante observar a plástica existente entre essas fotografias. $\mathrm{Na} 2$, um homem, numa posição central, parece chocar a sua família; na 6, uma mulher, numa posição deslocada com relação a um outro dançarino e cujas mãos se abrem para o alto, como uma bela flor de lótus fecundada.

\section{Referências bibliográficas}

ARNHEIM, R. El pensamiento visual. Trad. de Rubén Masera. Barcelona: Paidós Ibérica, 1998. [or. inglês, 1969].

AUMONT, J. À quoi pensent les films. Paris: Séguier, 1996.

Cad. Cedes, Campinas, vol. 26, n. 68, p. 21-38, jan./abr. 2006

Disponível em <http://www.cedes.unicamp.br> 
Imagens de velhice, imagens da infância: formas que se pensam

BARTHES, R. La chambre claire: note sur la photographie. Paris: Seuil, 1980. [Versão portuguesa: BARTHES, R. A câmara clara: nota sobre a fotografia. 2. ed. Rio de Janeiro: Nova Fronteira, 1984].

BORGES, J.L. El Aleph. Paris: Gallimard, 1977. (L'imaginaire, 13). [or. Castelhano. 1949).

BRUNO, F. Retratos da velhice: um duplo percurso metodológico e cognitivo. 2003. 294f. Dissertação (Mestrado) - Programa de PósGraduação em Multimeios, Instituto de Artes, Universidade Estadual de Campinas, Campinas.

CHRISTIN, A.-M. L' image écrite ou la déraison graphique. Paris: Flammarion, 1995.

DIDI-HUBERMAN, G. L'image survivante: histoire de l'art et temps des fantômes selon Aby Warburg. Paris: Minuit, 2002.

DUBOIS, P. Cinema, vídeo, Godard. São Paulo: Cosac Naify, 2004.

GODARD, J.-L. Histoire(s) du cinema 3: la monnaie de l'absolu; une vague nouvelle. Paris: Gallimard-Gaumont, 1998.

GOMBRICH, E. Aby Warburg: an intellectual biography with a memoir on the history of the library by F. Saxl. Oxford: Phaidon, 1970.

MERLEAU-PONTY, M. L'oeil et l'esprit. Paris: Gallimard, 1964.

MICHAUD, P.-A. Aby Warburg et l'image en mouvement. Paris: Macula, 1998

SAMAIN, E. Oralidade, escrita, visualidade: meios e modos de construção dos indivíduos e das sociedades humanas. In: JunQueIRA FiLHo, L.C.U. (Coord.). Perturbador mundo novo: história, psicanálise e sociedade contemporânea, 1492-1900-1992. São Paulo: Escuta, 1994. p. 289-301. 